\title{
Analysis on the Current Situation and Future Development of Sneaker Resale Market
}

\author{
Zhang BoPing
}

\author{
Dalian American International School, China, 116600 \\ ${ }^{*}$ Corresponding author. Email: 13898689330@163.com
}

\begin{abstract}
Sneaker resale market is where sellers and buyers conduct transactions of sneakers released in primary market. People can buy cheaper, scarce, or collaboration shoes in this market. The price of every pair of sneakers also fluctuate due to many factors. The purpose of this paper is to explore the reason of why the sneaker resale market has quickly become a heated topic in recent years. The finding will be demonstrated in the form of analysis which followed along with the empirical finds, common phenomenon and personal experiences.
\end{abstract}

Keywords: Sneaker, resale market, sneaker reseller

\section{INTRODUCTION}

It's not rare to see that people who dress fashionably always wait and crowd in front of the shopping mall at 6:00 in the morning every day when NIKE and Adidas released new sneakers. Some of them are 60 to 70 years old elders wearing Air Jordan shoes and Nike shirts which neither fit their ages nor public atheistic. People swarm and crawl into the mall through the gap between the ground and the rolling door rose up. They rush to the sneaker store where the new sneaker is released, expecting to get a lucky ticket and a chance of buying those shoes. It's not hard to tell that in recent years, people are so crazy about sneakers which even deprive them from some ethical rules. The core reason that can explain this ridiculous phenomenon is not pure about the shifted taste and preference, but is based on various factors. Moritz Lux and Peter Bug have done elaborated research and found a complementary relationship between sneaker brands and the resale market. They claimed that the sneaker resale market is widely fragmented and this condition will probably not change in the future because of different preferences for sellers and buyers .[1] There are rare findings which investigate and explain why the sneaker resale market boom in recent years. So, the author is going to share my thought and analysis based on empirical findings to fill this opening as a sneaker lover.

\section{BACKGROUND}

During the last century, the sneaker resale market made the first appearance and gradually attracted public attention. In 2011, Nike company releases "Nike Air Mag" in order to commemorate film called Back to The Future II. There are only about 1500 pairs of them. The scarcity made the sneaker extremely expensive. British rapper, Tinie Tempah finally bid for it at a price of 37500 dollar.[2] In addition, in 2009, Nike collaborated with famous rapper Kanye West, the spokesman of Nike as well, together designing and releasing the sneaker "Air Yeezy". After 4 years, Kanye canceled the contract with Nike due to some private conflicts and then collaborated with Adidas, the other head of oligopoly of sneaker market. The leave of Kanye West made "Air Yeezy" an epilogue of the collaboration of West and Nike. This news immediately spread in sneaker heads and resellers and finally became a factor that rose up the price of "Air Yeezy", which ranged from 1999RMB when it's released to 99999RMB right now, nearly 50 times more than before.[3]Thus, these two examples perfectly reveal the phenomenon that the scarcity is never the only factor from which resellers take advantages to inflate the price. The story behind the sneaker plays a more significant role. On social platforms, some also share their personal predictions of the future situation of sneaker resale market, claiming that sneaker market won't crash but only sustainably grow. 
Indeed, seemingly, current data of eBay sneaker sales about the value of sneaker resale market indicates a continuous growth. Since 2012, the resale market has reached the new peak every year. In this article, the author is going to analyze multiple factors that contribute to the boom of sneaker resale market.

\section{RESELL SNEAKER MARKET = EBAY $\times 3=\$ 1$ BILLION}

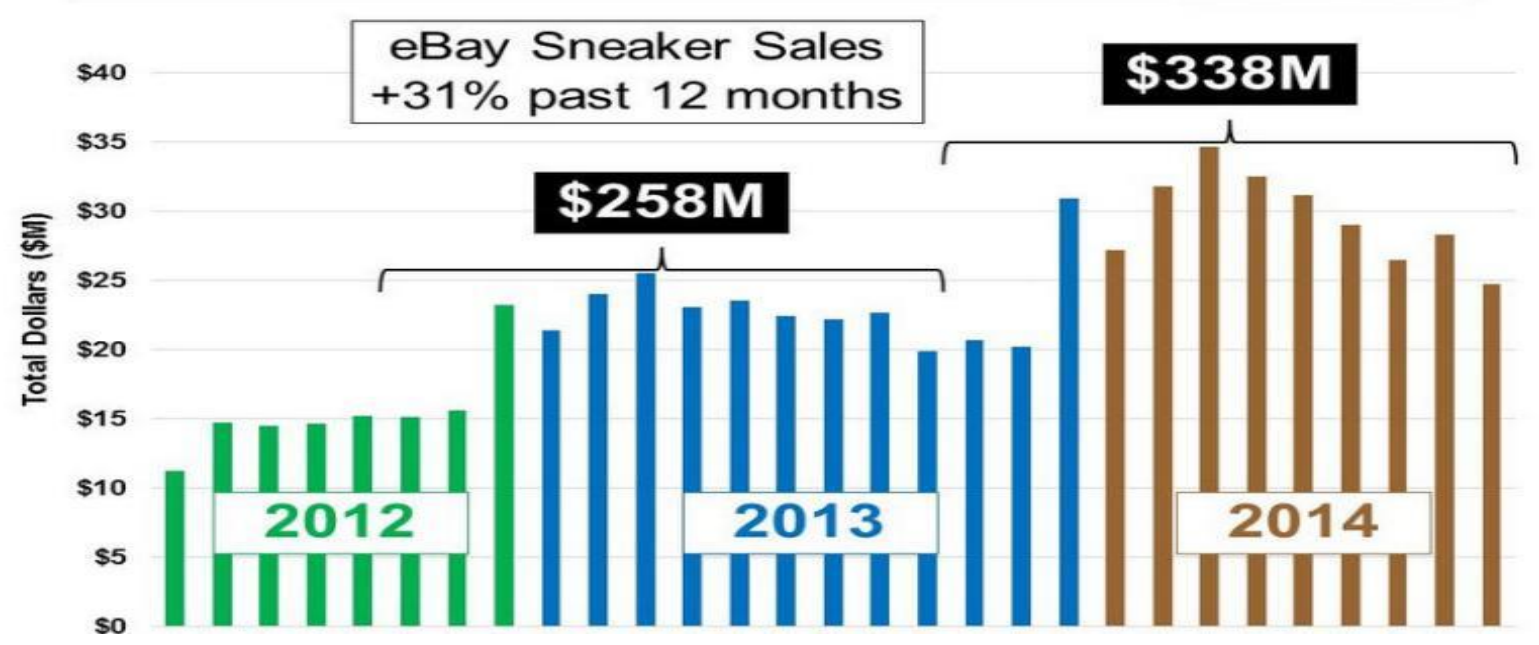

Figure 1. Index of the Value of Sneaker Resell Market [4]

\section{THE DISORDER OF CONSUMPTION PSYCHOLOGY}

Originally, the reasons for people to buy sneaker are quite simple, such as for pursuing fashion, comfort, and even new technique. However, in recent years, as new collaborations with starts and the limited edition emerged in consumers' view. The core reason of purchasing sneakers has gradually changed. Sneakers no more served for practical uses but became a luxury, a collection, even a transaction for money consideration. Under this condition, a new profession emerged--Sneaker Reseller. The professional sneaker resellers always work together, aiming to one popular sneaker every time. They spend lots of money to purchase that sneakers right after it is released. As a result, they own all storage of that sneaker and thus set up easily and manipulate the price in the resale market. More importantly, there are also other sneaker reseller try to seek profit in quite similar way. StockX, Goat, POIZON are the new-born applications which grew along with the sneaker market. These sneaker resellers utilize them as platforms of resale market where they could sale and buy sneakers. What's more, these applications provide them with clear linear graphs which indicate the change in price of every single sneaker from the day it was released. By analyzing the graph, they purchase and sell sneaker in order to seek greatest profit.

Obviously, the sneaker resale market might remind people of stock market which work in the same way. However, the sneaker resale market provides people with much more chances of access and profit.

\begin{tabular}{|c|c|c|c|}
\hline 2-Year & $\begin{array}{ll}142.00+160.89 \% & \\
\text { on } 01 / 03 / 19 & \text { Period Open: } 193.00\end{array}$ & $\begin{array}{r}399.82-7.34 \% \\
\text { on } 07 / 13 / 20\end{array}$ & $\begin{array}{l}+177.46(+91.95 \%) \\
\text { since } 07 / 24 / 18\end{array}$ \\
\hline 3-Year & $\begin{array}{l}142.00+160.89 \% \\
\text { on } 12 / 31 / 18 \text { Period Open: } 149.50\end{array}$ & $\begin{array}{r}399.82-7.34 \% \\
\text { on } 07 / 13 / 20\end{array}$ & $\begin{array}{l}+220.96(+147.80 \%) \\
\text { since } 07 / 24 / 17\end{array}$ \\
\hline 5-Year & $\begin{array}{l}89.47+314.06 \% \\
\text { on } 05 / 09 / 16 \quad \text { Period Open: } 121.30\end{array}$ & $\begin{array}{r}399.82-7.34 \% \\
\text { on } 07 / 13 / 20\end{array}$ & $\begin{array}{l}+249.16(+205.41 \%) \\
\text { since } 07 / 27 / 15\end{array}$ \\
\hline 10-Year & $\begin{array}{l}33.65+1,000.87 \% \\
\text { on 08/01/10 Period Open: } 36.75\end{array}$ & $\begin{array}{r}399.82-7.34 \% \\
\text { on } 07 / 01 / 20\end{array}$ & $\begin{array}{l}+333.71(+908.05 \%) \\
\text { since } 07 / 01 / 10\end{array}$ \\
\hline
\end{tabular}

Figure 2. Index of Apple Stock in 10 Years [5] 


\section{LATEST SALES}

Zoom 1M 3M 6M YTD $1 Y$ All

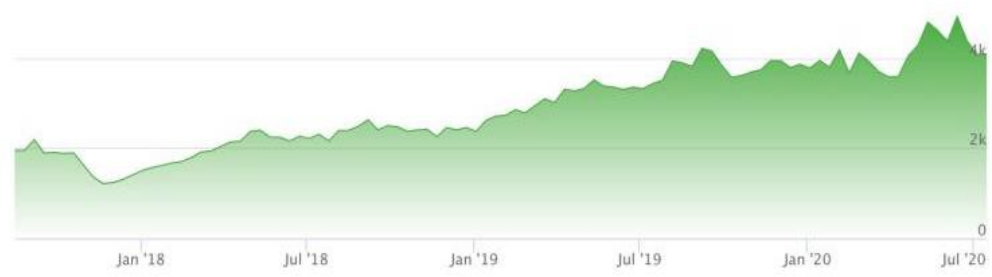

View All Sales

SIZE

9.5

10

10

11

12

SALE PRICE
$\$ 4,202$
$\$ 3,932$
$\$ 4,000$
$\$ 3,875$
$\$ 4,150$

DATE

Saturday, July 25,2020

Saturday, July 25, 2020

Friday, July 24,2020

Friday, July 24, 2020

Friday, July 24, 2020
TIME

3:24 PM EST

3:23 PM EST

11:08 AM EST

10:57 AM EST

10:51 AM EST
(1) 12 MONTH HISTORICAL

\# OF SALES

563

PRICE PREMIUM

(OVER ORIGINAL RETAIL PRICE)

\section{$2111.6 \%$}

AVERAGE SALE PRICE

$\$ 3,958$

Figure 3. The price Index of Off-White*Air Jordan 1 Retro Chicago [6]

It's easily to see that in 10 years, the share of Apple (the well-know, No.1 brand of phone around the world) merely grew to $908.05 \%$ of the original value. However, the price of off-white*Air Jordan 1 Retro Chicago has grown to $2111.6 \%$ of its original one since it was released on September 9th 2017. The difference is clear. The sneaker resale market builds a platform for people to quickly earn mint. What's more, there is no limitation of age in sneaker resale market. It means that the kids from primary school could even also earn great profit by buying and reselling sneakers in this free monophonic market.

\section{SCARCITY \& TOLERANCE \& STABILITY}

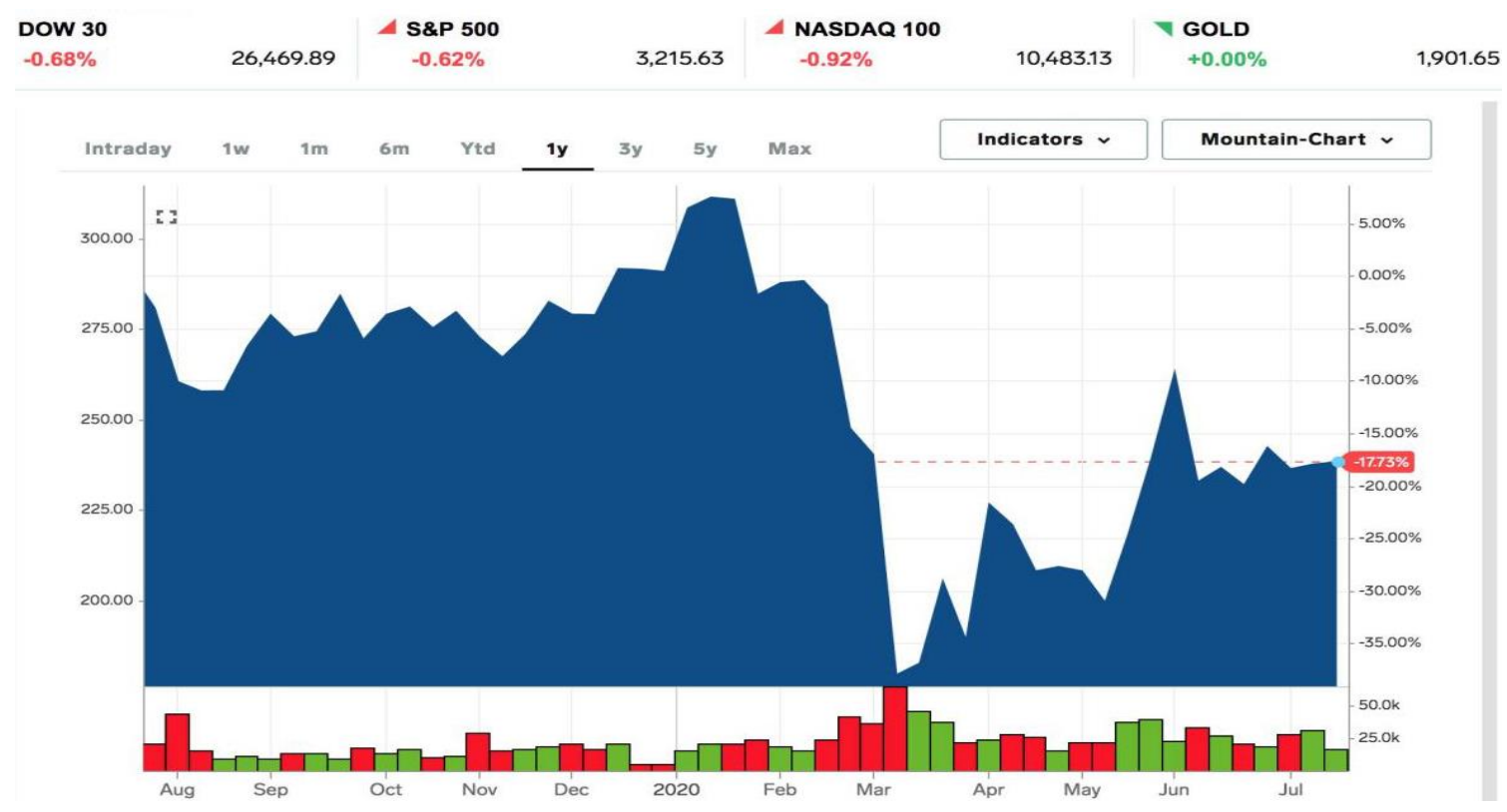

Figure 4. Index of Adidas Stock Price [7] 


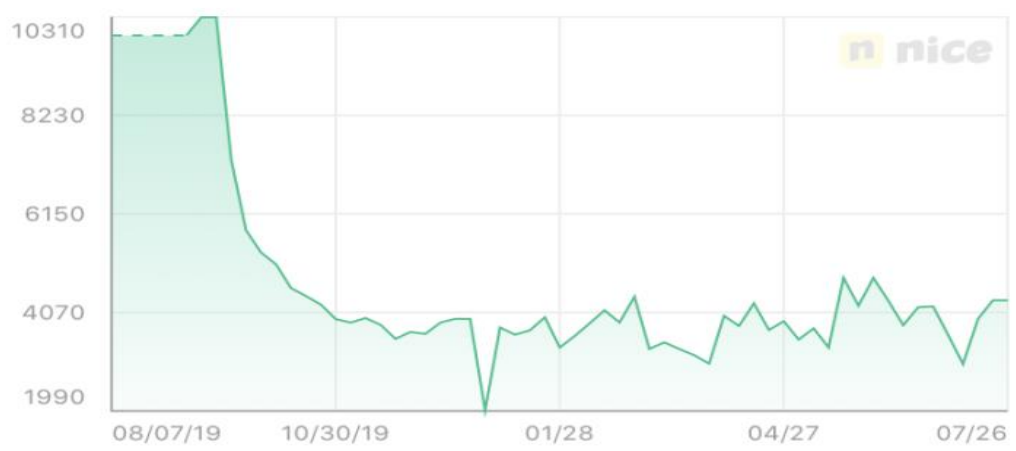

Figure 5. The Index of Average Price of YEEZY 700 V3 “AZAEL” [8]

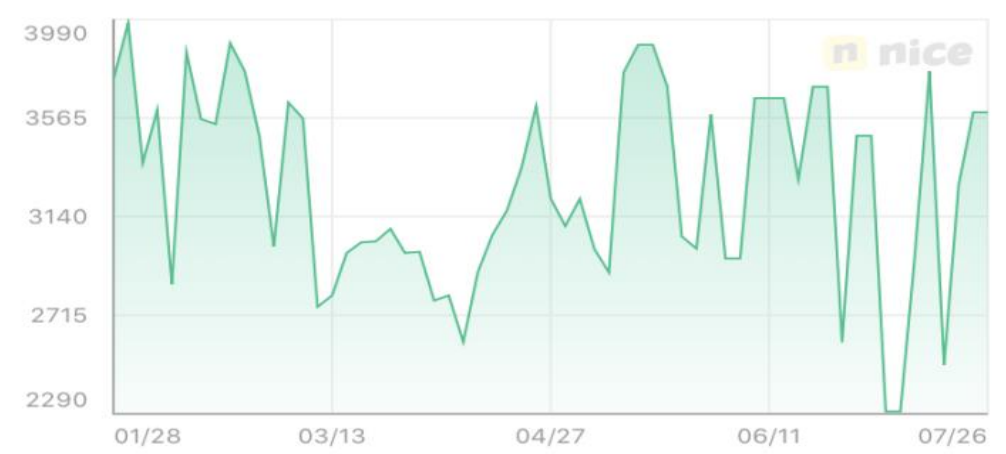

Figure 6. The Index of Average Price of YEEZY 700 V2 "GEODE” [8]

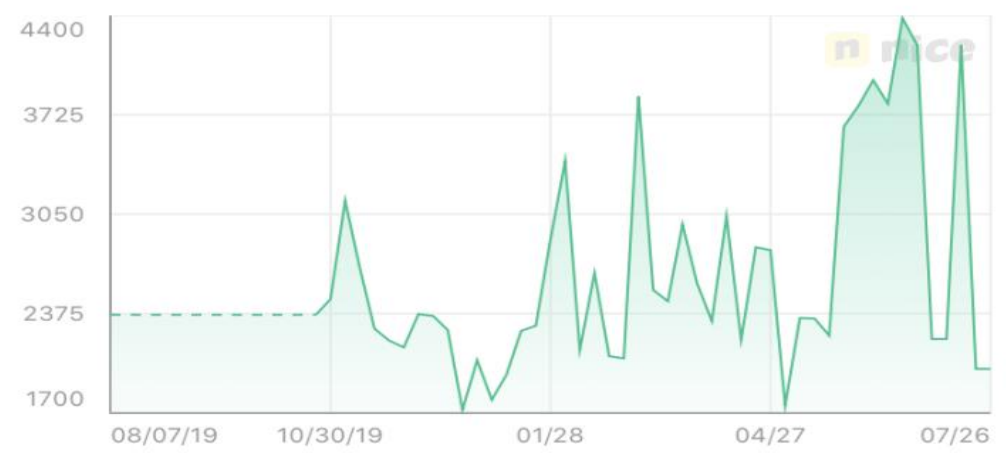

Figure 7. The Index of Average Price of Adidas Pharrell NMD Human Race China Pack Peace [8]

At the beginning of this year, COVID-19 greatly harm global economy. Sneaker market was negatively affected as well. Through Figure 7, the graph of Adidas stock market's trend in one year, it's obvious to see that during March, a dramatic decline took place. This was probably due to the influence of COVID-19, most retail stores were forcefully closed in the primary market in order to prevent people from gathering.

Figure 8, 9, and 10 are the three graphs that indicate the price trends of three Adidas sneakers randomly sampled in the resale market. Indeed, during March, only $8 \%$ people expressed willingness to do more shopping after the outbreak (Li). [9] Through the graph, however, it's obvious to see that during march, the price of each single shoes didn't fluctuate too much. It's puzzling that when comparing with the primary market, the resale market is unlikely to be influenced.
The answer is quite clear that sneakers in resale market remain scarce and are likely to be well preserved in the storages after resellers widely purchased. The higher scarcity prevents their prices from dropping below the original price when they are first released. Moreover, resellers could sale those sneakers in the resale market whenever they what and whenever there is demand. If NIKE chooses to prolong the date of releasing new sneakers, they will only lose their own credibility. On the other hand, if NIKE chooses to release some less expected sneakers first and keep those expected sneakers not for public sale until the epidemic leave, they will only loose consumer's expectation. Either ways will indirectly lead the value of company decline. So, in contrast, the sneaker resale market shows greater tolerance and elasticity while encountering certain unpredictable incidents. 


\section{COMPARISON AND CONTRAST WITH TULIP BUBBLE ECONOMY IN NETHERLANDS}

In the late 1500 century, tulip was fist imported to Netherland in Western Europe from Turkey. It usually took more than 15 years to grow and hard to be cultivated before flowering.[11] Thus, the scarcity of tulip created barriers for people who seek for profit to entry the market and also contributed to the increase of price later. During that time, there was a particular type of tulip called "Broken bulbs", the one with striped patterns caused by mosaic virus strain, stood out among thousands of tulips with single color. [12] People made up stories about the "broken bulbs" which dramatically drove up the demand of it in the market. The graph above not only demonstrate the change in price of Tulip, but also reveals the shift of consumption psychology. During the Awareness phase, people saw a slight increase in the price of Tulip market and gradually deem Tulip as a luxury, spending money on it for satisfaction rather than appreciation. Only one year later, however, the price of tulip showed a dramatic increase. This change draw people attention to tulip market: nearly all people participate into the tulip market, no matter rich and poor. Trading tulip becomes the best way to earn quick money. Yet, in 1637 the tulip market crashed. The price of tulip gradually became out of control, growing so fast that some trader couldn't afford it. According to Tulipomania: The Story of the World's Most Coveted Flower and the Extraordinary Passions It Aroused written by Mike Dash, the price of certain Tulips is enough to feed, clothe and house a whole Dutch family of half a lifetime, or sufficient to purchase one of the grandest homes on the most fashionable canal in Amsterdam for cash. Under this condition, people began to buy tulips with leverage, using margined derivatives contracts to buy more than they could afford.[13] As the price of tulip became ridiculous, the economic pressure on seller goes up as well. At the same time, less and less people are willing to buy them: the demand became less than the supply. Finally, someone determined to break the price floor and leave the free competitive market, selling the tulip in a relatively lower price. This action triggered the domino effect: seller scrambled to reduce the price of tulip in order to be competitive. As a consequence, the tulip market crashed: every item was back to the normal price.

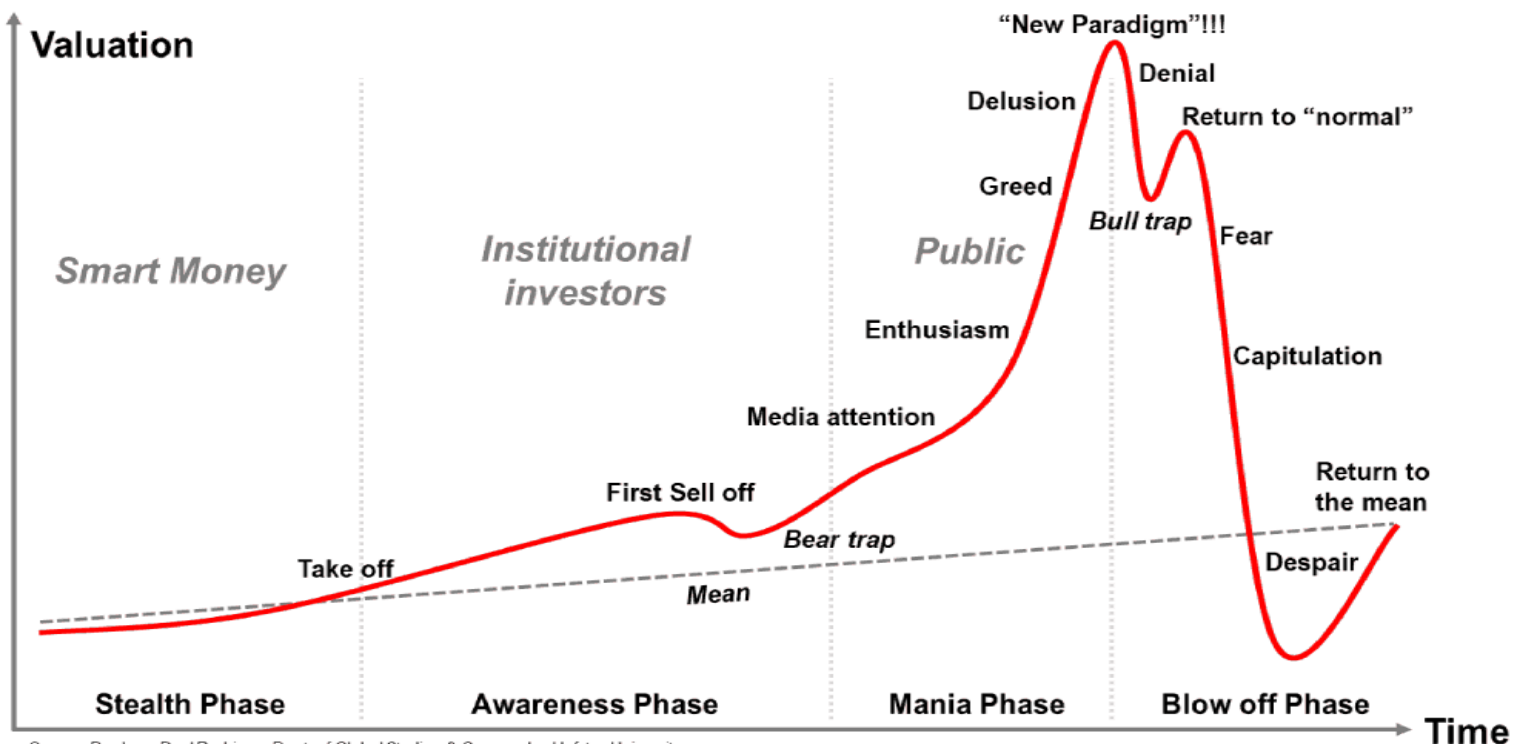

Figure 8. The Index of Tulip Market during Tulip Bubble [10]

Indeed, the current situation of sneaker resale market seems so similar with that of Tulip market in Netherland. However, the sneaker resale market is unlikely to crash.

The answer is obvious that differences do exist. The reason why tulip market crashed is the uncontrollable and vacuous growth of its price. Yet, both the original function of sneaker and the government and public force contribute to limitation of the price of sneakers, preventing it from being out of control.
For starters, the original function of sneakers is different from Tulip. The former is for protection and comfort for foot and the latter is for appreciation. The primary function of sneakers is fairly practical: no matter how scare they are, people are prone to wearing them rather than putting them into glass-frame cabinet forever. However, to tulip, people are likely to deem them as an artwork because they not only could be kept for a longer time, but also consist with some features and serve the same function of artwork: they are fragile and merely for appreciation. People will spend more time and effort on taking care of tulip. In contrast, 
sneakers are easily damaged as long as people wear them and oxidized which is inevitable. So, when consumers are purchasing sneakers, they usually pursue a balance between the practicality and price. People won't be willing to spend too much money on sneakers for appreciation. In this case, the demand of scare and limited collaboration (high-price) sneakers will never be as high as the demand of scare tulip. As a result, price of sneakers won't go extremely high due to the relatively stable and demand.

Secondly, nowadays, the government also plays a crucial role of limiting the price of sneakers. In the morning on January 26th 2020, a star fell. Kobe Bryant was declared dead. [14] Once the news spread, the price of any single sneaker and T-shirt related to Kobe on the sneaker trading application dramatically increased because some people were attracted by profit and abandoned ethical rule. However, when the price continuously grew, public started to criticize these seller's such an anti-human behavior: earning money by died people. Eventually, under the great public force, the government stood out and stopped this crazy behavior. POIZON and NICE, two Chinese sneaker trading application, took down all Kobe related products at January 27 th 2020 , the day after Kobe was declared dead .[15] All sellers could no longer trade Kobe shoes and clothes through the application.

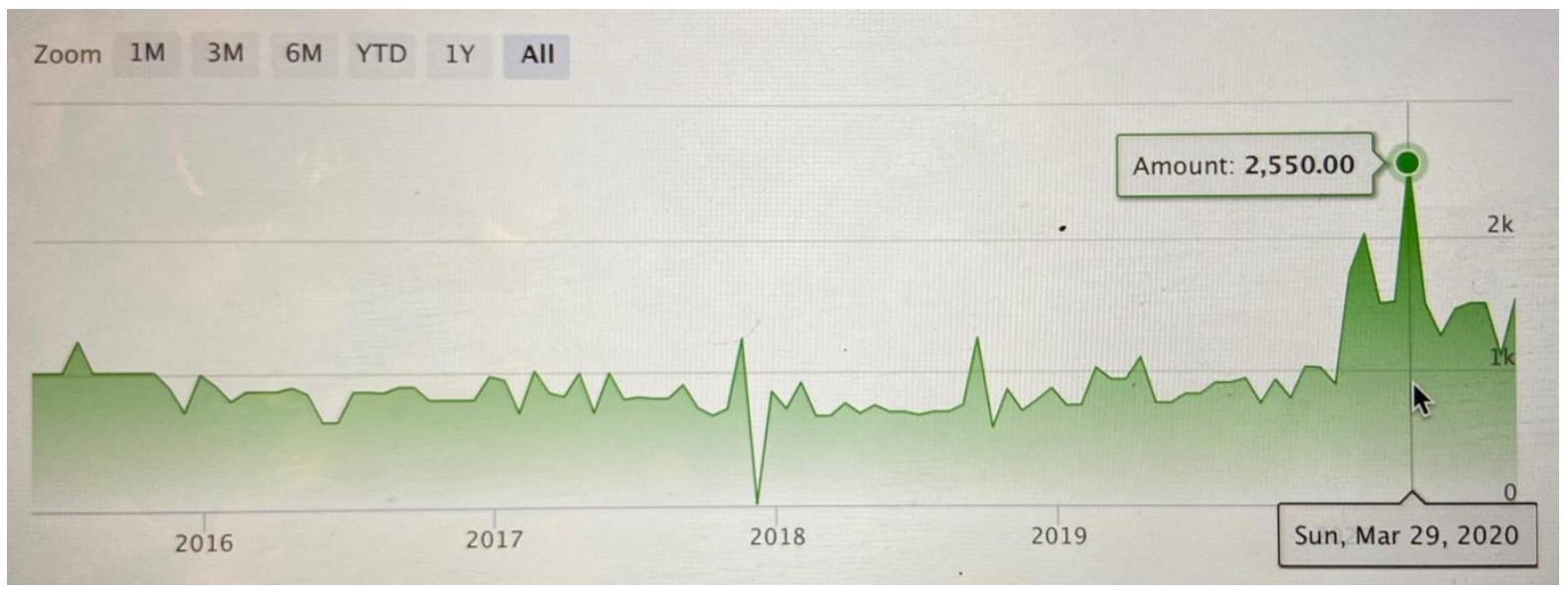

Figure 9. The Index of price of Nike Kobe 6 Grinch [16]

Figure 9 is produced by Stock $X$ was the index of price of Nike Kobe 6 Grinch. It indicates a startling growth of price in the days after Kobe died. However, the price was only kept for days and quickly backed to the normal due to the low public demand. Obviously, the initial and original function of sneakers make itself hardly get rid of its definition. Thus, there is unlikely to be a breakthrough on the price of sneakers. Besides, the great force of public and government also prevents the price of sneaker from drastically increase, ensuring it is unlikely to be a way for sellers who extremely seek profit and take advantage from any process.

\section{CONCLUSION}

The flourishment of sneaker resale market is not and coincidence or an accident, rather it is an unbreakable fact which probably last for a long time. The high profit and appropriate marketing environment widely attract people to access to the market. The market's property and the conveniences create benefit for resellers and help to promote the development of the market. Additionally, there are various factors which positively suppress the sneaker resale market, preventing it from excessively growing and thus contributing to the stable and long-term development. Although, there are several potential risks such as the oxidation of sneakers and the change of taste and preference along with the age. The new technology, the complementary products of sneaker nursing, new styles and technology adopted along with new generations could insure that the sneaker market won't crash in the short-term.

\section{ACKNOWLEDGMENT}

I would like to extend my sincere gratitude to my supervisor for her instructive advice and useful suggestions on my paper.I am deeply grateful of her help in the completion of this paper.

\section{REFERENCES}

[1] Lux, Moritz, and Peter Bug. Sole Value - the Sneaker Resale Market: an Explorative Analysis of the Sneaker Resale Market." ResearchGate, Reutlingen, Germany,1 Jan. 2018

[2] Perpetua, Matthew. Tinie Tempah Buys 'Back to the Future' Sneakers for \$37K. Rolling Stone, 25 June 2018, www.rollingstone.com/music/musicnews/tinie-tempah-buys-back-to-the-futuresneakers-for-37k-182579/

[3] Gorsler, Fabian, et al. Kanye West Is Cool with Nike Re-Releasing His Air Yeezy Line. Highsnobiety, Open Menu Highsnobiety 
Logo All News Black Lives Matter Style Sneakers Back-to-School Shop Search, 17 Apr. 2020, www.highsnobiety.com/p/kanye-west-nike-airyeezy-retro/

[4] Lutz, Ashley. Nike Could Be Missing Out On A Billion-Dollar Opportunity. Business Insider, Business Insider, 17 Oct. 2014, www.businessinsider.com/nike-resell-sneakermarket-analysis-2014-10.

[5] Price Performance.Barchart.2020. https://www.barchart.com/stocks/quotes/AAPL/per formance

[6] StockX, https://stockx.com/air-jordan-1-retro-highoff-white-chicago

[7] Index of Adidas Stock Price. 2020. https://markets.businessinsider.com/stocks/adidasstock

[8] Nice.2020. http://www.oneniceapp.com

[9] Li, Jane. Cutting off Trivial Things: Chinese Consumers Are Thinking Twice about Their Post-Coronavirus Spending. Quartz, 6 Apr. 2020. qz.com/1830777/china-consumers-wary-ofspending-after-coronavirus/.

[10] Stages in a Bubble. The Geography of Transport Systems.2020. FIFTH EDITION. Jean-Paul Rodrigue (2020), New York: Routledge, 456 pages. ISBN 978-0-367-36463-2

[11] Teo Spengler, Teo. My Tulip Tree Isn't Blooming - When Do Tulip Trees Flower. 2020.3.17 www.gardeningknowhow.com/ornamental/trees/tu lip-tree/when-do-tulip-trees-flower.htm.

[12] Klein, Joanna. Broken Tulips: 'That Last Gasp of Beauty Before Death'. The New York Times, The New York Times, 11 May 2017. www.nytimes.com/2017/05/11/science/brokentulips.html

[13] Hayes, Adam. History of the Dutch Tulip Bulb Market's Bubble. Investopedia. 29 Jan. 2020, www.investopedia.com/terms/d/dutch_tulip_bulb_ market_bubble.asp

[14] Press, Associated. Kobe Bryant, All Others Aboard Helicopter Died Immediately in Crash, Autopsies Show. ESPN, ESPN Internet Ventures, 15 May 2020, www.espn.com/nba/story/_id/29180785/kobebryant-helicopter-pilot-had-no-drugs-alcoholsystem-autopsy-shows

[15] Jiang, Yaling. Chinese Sneaker Trading App Poizon Takes Down All Kobe Products \& More. Jing Daily, $30 \quad$ Jan. 2020. jingdaily.com/chinese-sneaker-trading-app-poizontakes-down-all-kobe-products-more

[16] Stock. 2020. https://stockx.com/kobe-6-grinch 